Revista IBERC

v. 4, n. 1, p. 190-196, jan./abr. 2021

www.responsabilidadecivil.org/revista-iberc

\title{
DISCURSO DO PROFESSOR DOUTOR RENAN LOTUFO NA FORMATURA DA TURMA JOSÉ FREDERICO MARQUES DA PUCSP EM 29/03/1994
}

Caros amigos da Turma Tosé Frederico Marques noturnat

Oswaldo Aranha, brasileiro que se notabitizou por ser o representante do Brasil na reinstalacáo da oNu assim definiu a minha fungaro de paraninfo "t: 0 professor a quen incumbe a altima liço e o amigo a quern cabe o primeiro consethon"

A dificuldacle " depois de tantas aulas" em

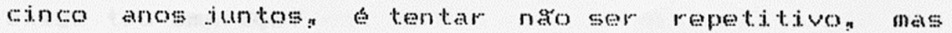
algumas ideias temos que repetir, por serem expressao do que cremos"

CHESTEFTON, pensador ingles: dixia que " Iogico qur enfiar o ceu na cabegan o poeta quer enfiar a cabega no cen"

No momento historico em que vivernos " no Fais, na Fuc, no mundo enfim, parecen certas as rimas de AFFONSO FOMANO DE: SANT ANINA:

"Mentiram-me ontern e hoje mentem novamente..

Menterm de corpo e alma completamenten

E menten de maneira taro pungente. que acho que mentem sinceranente.

(.. E) E de tanto mentir tåo bravamente, constroen un pass de mentira diariamente " 


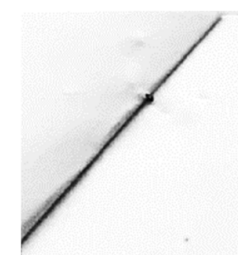

Mas, aí e que se sente a falta do estudo e da c.:iencia porque a recepcáo a aceitacáo da mentira tem muito a ver com a ignorancia do receptor.

A satisfacáo com o grau obtido tem ensejado a estagnacaro intelectual.

1:: de se lembrar a passagem ocorrida com EFTCTETO:

"E, a que se conta no governo de Marco

Aurelio, perguntava o estoico ao Fretor da Grecia

-..- Sabes tu julgar? Aprendeste a cioncia que

exige teu emprégo?

Fesponde o pretor:

-.- Tenho a nomeacaro de Cesar. que me basta.

Mas of fi. osofo redarguiu:

- E pode ela dar-te a jurisprudencia que te

falta, e se faz indispensavel no exercicio do teu

cargo?"

A necessidade de aprofundamento e contiuidade no estudo, e essencial. ao Direito e a busca da Tustica.

Os grandes cientistas é quem nos ensinam, no entanto" que nåo basta o estudo da ciencia pura " no plano asceticoe meramente formal.

ETwStEL ja ensinava"

"Wáo basta o conhecimento da cienica aplicica

para que o vosso trabatho traga mais beneficio ao 

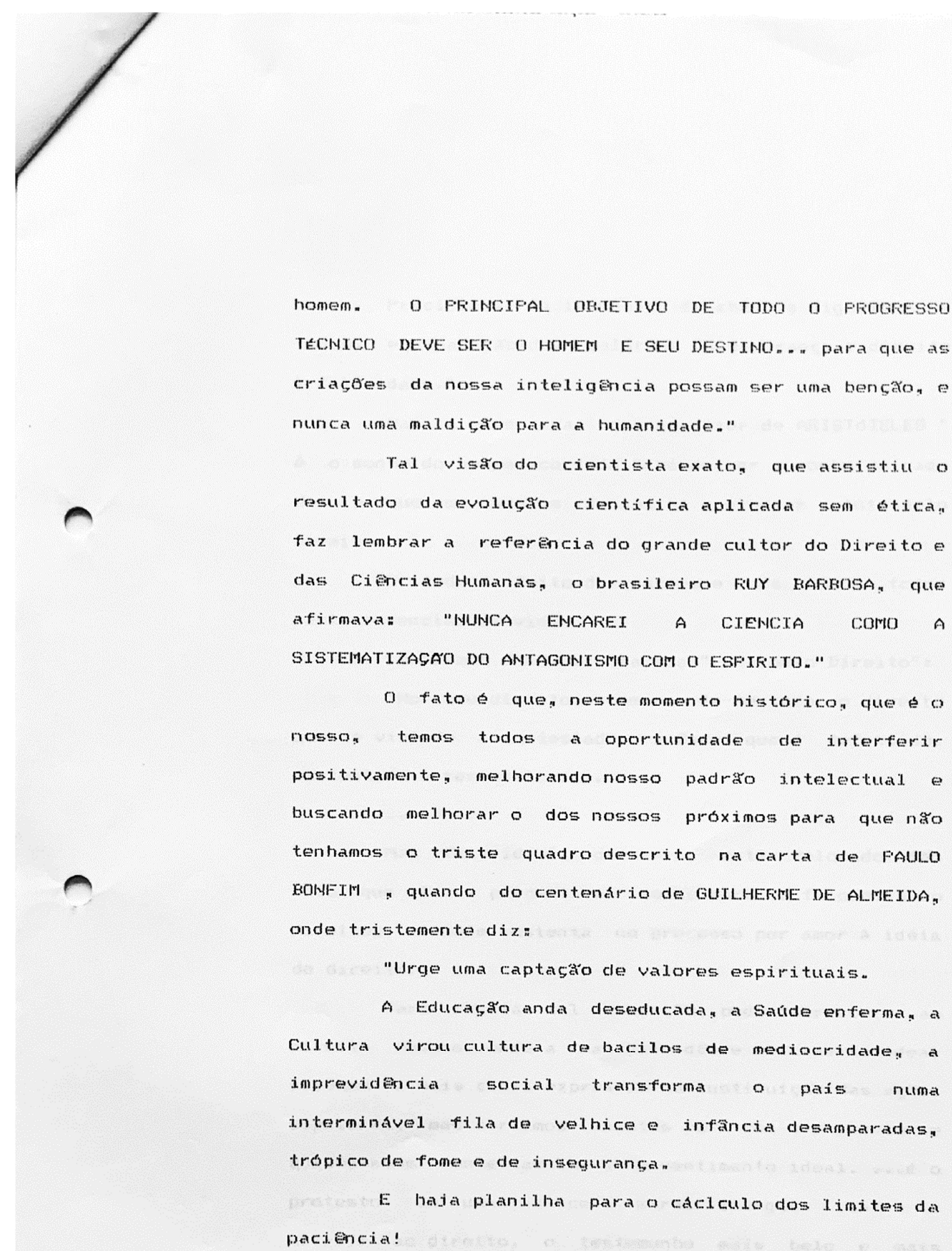


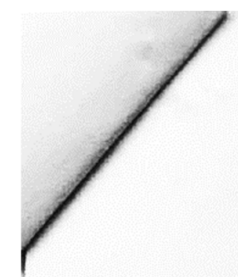

Frecisamos da isonomia de chances iguais para todos, equiparaçáco dos salários da esperança e direito a felicidade."

Mass a esperanga, que no dizer de ARTSTótel.ES " E o sonho do homen acordado." há de ser o sonho de cada dia porque en cada um de nós há que haver a luta pelo Di. reito.

o todo é feito de partes e nós somos todos parte essencial da vida.

Lembremos JHERING: " na sua "Luta pelo Direito" "

"No meu direito, compreende-se todo o direito que é violado e contestados ésse que e clefendicton sustentado e restabelecido.

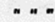

Fara refutar tal asserço, poderia recorrer ao clireito romano, onde a realidade desse sentimento ideal recebeu a mais clara expressaro na instituigáo das aças populares" mas seriamos injustos para com o presentes se qui.sésumos contestar-1he este sentimento ideal. . ... o protesto de uma natureza moral energica contra o ultraje ao direito" o testemunho mais belo e mais 

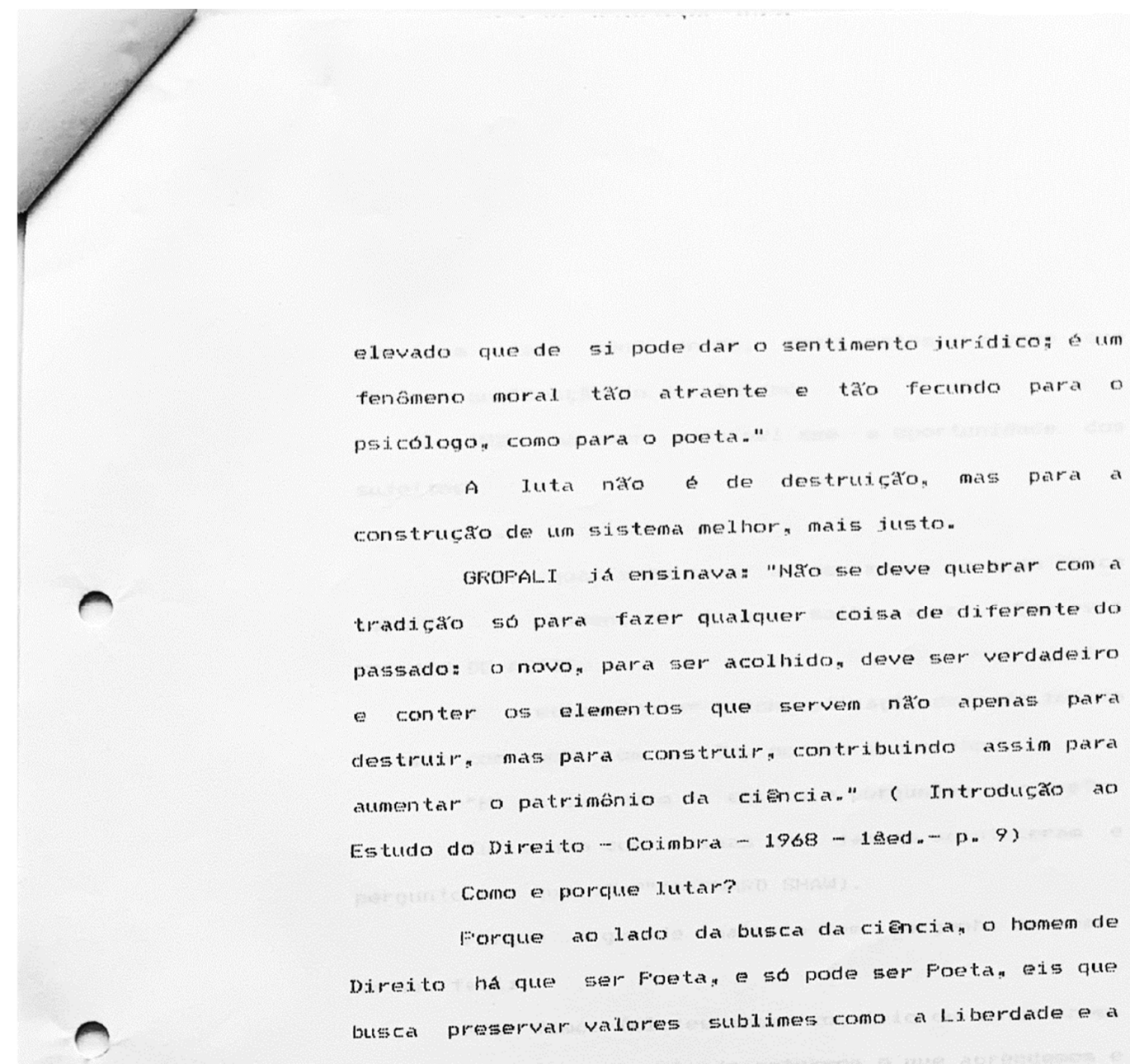

A Juta náo é de destruiça mas para a construça de un sistema melhor, mais justo.

GROFALI ja ensinava: "Nao se deve quebrar com a tradiça so para fazer qualquer coisa de diferente do passado: o novo. para ser acolhido. deve ser verdadeiro - conter os elementos que serven nao apenas para destruir. mas para construir, contribuindo assim para aumentar o patrimönio da ciencian" ( Introduço ao Estudo do Direito - Coimbra - 1968 - 1ded..- p. 9)

Cono e porque lutar?

Forque ao lado da busca da ciencia, o homen de Direito há que ser Foeta, e so pode ser Foetan eis que busca preservar valores sublimes como a Liberdade e a Tustiga.

E do poeta portuguess FEFNANDO FESSOA a idéia que sintetiza o Logico e o Foeta de CHESTEFTON:

"Nasci sujeito como os outros a erros $e$ defeitos." mass nunca ao erro de querer compreender só com a inteliciencia."

Noo e possivel deixar passar a oportunidade de 50. Viver com amor, com paixaro pelos entes que nos 


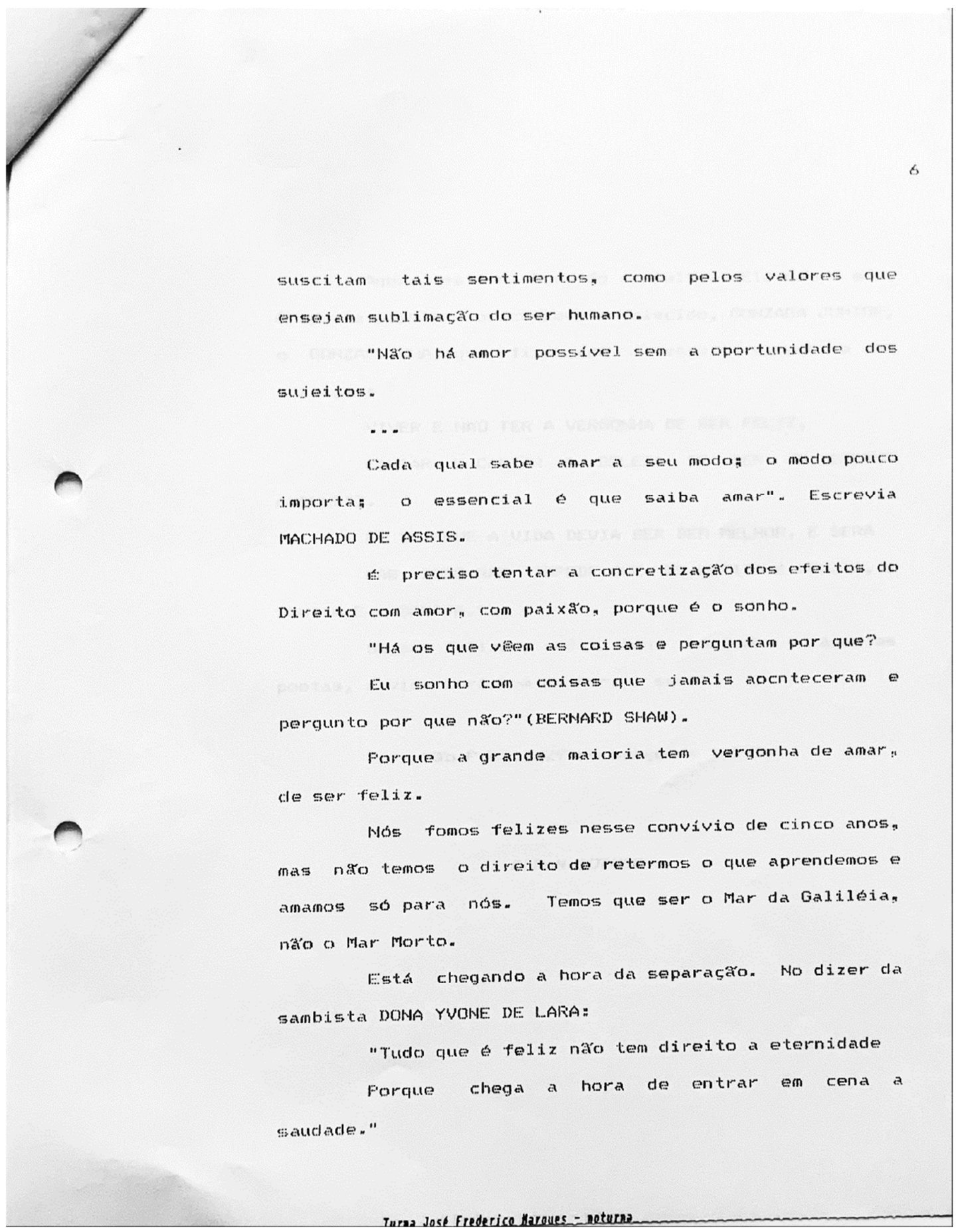




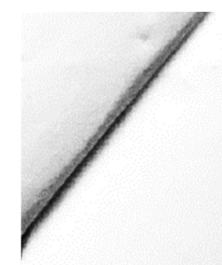

Agora está na hora do conselho. Ele nao é meu, é poeta popular precocemente falecido, gonzaga runtor, - gonzagumhan que ficou com a resposta da pureza das criangas:

UTVER E HAO TER A VERGONHA DE SEF FELTZ, CANTAFi E CANTAF: A RELEZA DE SER UM ETEFHO AFRENDIZ.

EUU SEI QUE A UTDA DEVTA SEF REM MEL.HOR , E SERA MAS ISSO NAO TIFEDE QUE EU REFTTA E RONTTA, E BOWITA E E RONITA."

Sejan felizes "sejam bons logicos e amantes poetas, a vida sera bem melhor" e sera!

Săo Faulo, 29 de margo de 1.994.

RENAN LOTUFO 